\title{
Targeting oncogenic drivers in lung cancer: celebrating a decade of progress
}

\author{
Oliver Gautschi · Joachim Diebold
}

Received: 18 November 2014 / Accepted: 16 December 2014 / Published online: 9 January 2015

(C) Springer-Verlag Wien 2014

In the past decade, remarkable progress was achieved in the field of targeted therapy for patients with advanced non-small cell lung cancer and oncogenic driver mutations. From a clinical point of view, it all began in 2004, when three groups independently discovered the predictive role of activating epidermal growth factor receptor (EGFR) mutations for EGFR tyrosine kinase inhibitors [13]. Five years later, the promise of "targeted therapy beats chemotherapy" was fulfilled for the first time in thoracic oncology, when the pivotal IPASS trial demonstrated superior activity of gefitinib compared with first-line chemotherapy in patients with activating EGFR mutations [4]. This was confirmed by a number of follow-on trials with different EGFR inhibitors, including erlotinib and afatinib [5]. In 2007, EML4-ALK fusion in lung cancer was discovered, leading to the rapid clinical development of crizotinib [6]. Again, the pivotal PROFILE trials demonstrated superiority of crizotinib over first- and second-line chemotherapy in patients with ALK rearrangement $[7,8]$. Today, clinical research is focused on next generation ALK and EGFR inhibitors with improved activity in the central nervous system and against tumors with secondary resistance mutations $[9,10]$. In clinical routine, frontline targeted therapy is considered a new standard-of-care in patients with tumors harboring EGFR or ALK aberrations.

Combined, tumors with EGFR and ALK aberrations make approximately $20 \%$ of all nonsquamous lung cancers in Western populations. Further mutations exist with lower incidence $(<3 \%)$, for which targeted therapies have been used in analogy to other cancer types. In

\footnotetext{
O. Gautschi $(\varangle) \cdot$ J. Diebold

Department of Medical Oncology,

Luzerner Kantonsspital,

6000 Luzerne 16, Switzerland

e-mail: oliver.gautschi@luks.ch
}

2006, response to trastuzumab in a patient with human epidermal growth factor receptor 2- (HER2-) mutated lung cancer was reported [11]. This was exciting because the activity of trastuzmab in previous lung cancer trials had been only modest [12]. In 2013, a European cohort study provided further evidence to support HER2-targeted therapy in patients with HER2-mutated lung cancer [13]. In a phase I trial, neratinib and temsirolimus showed promising activity, and further trials with this combination are ongoing [14]. Recently, we reported successful treatment of a patient with HER2 mutation by ado-trastuzumab emtansine (T-DM1) [15]. A prospective clinical trial with T-DM1 is currently enrolling patients with lung cancer positive for HER2 by immunohistochemistry (NCT02289833). As HER2 expression and mutation are not the same, it will be interesting to see if this trial is using the right selection marker.

In 2012, the first results of a phase I trial with crizotinib in patients with ROS1 rearrangement were reported [16]. Because of the high degree of homology between the kinase domains of ROS1 and ALK, and the potent inhibition of ROS1 kinase by crizotinib, the results were excellent and confirmed in the final report in 2014 [17]. This trial had an immediate impact on clinical practice, as demonstrated by the EUROS1 cohort study [18]. The ongoing EUCROSS trial is expected to produce further relevant data (NCT02183870), while other studies are focusing on acquired resistance and other ROS1 inhibitors to overcome crizotinib resistance [19]. In 2012, we published a patient with BRAF V600E lung cancer responding to vemurafenib [20]. Vemurafenib and dabrafenib are approved for the treatment of patients with advanced melanoma harboring BRAF V600E. Recently, further patients with BRAF V600E lung cancer treated with vemurafenib were reported, and a phase I trial demonstrated good activity of dabrafenib [21-23]. A prospective phase II trial with vemurafenib is planned in France (registration number pending), and a retrospective 
cohort study is ongoing in Europe (EURAF). Of note, half of the BRAF mutations in lung cancer are located outside of codon 600 and may not respond to commercially available RAF inhibitors [24]. RET rearrangement in lung cancer was discovered by two independent groups in 2012 $[25,26]$. Preliminary results from an ongoing phase I trial suggested promising activity of cabozantinib [27]. Other reports suggested that vandetanib can also work [28-30]. Final results from the US trial with cabozantinib, and first results from the Japanese trial with vandetanib in patients with RET fusion, are awaited with great interest.

As stated in the 2014 National Comprehensive Cancer Network (NCCN) Guidelines, further druggable targets include MET, DDR2, and the list is growing [31]. Pathologists in many centers are currently implementing multiplex, high-throughput technologies to cope with the workload and provide clinicians with timely results. Quality control, expert knowledge, clinical experience, and interaction between pathologists and clinicians are more important than ever. We believe that patients with druggable mutations should preferentially be treated in accredited centers with clinical trial units and access to new drugs. Patients who are not eligible for clinical trials should be registered in cohort studies, such as the ones mentioned earlier. Even with the best available targeted therapies, metastastic lung cancers with druggable mutations progress early, many have mutations that are difficult to treat (for example KRAS mutations), and most have no druggable targets at all. Therefore, chemotherapy, combined with anti-angiogenic therapy, will remain indispensable in the foreseeable future. Continued research in this area, as well as in the field of immunotherapy, should not be neglected.

\section{Conflicts of interest}

Both authors declared no potential conflicts of interest.

\section{References}

1. Paez JG, Jänne PA, Lee JC, Tracy S, Greulich H, Gabriel S, Herman P, Kaye FJ, Lindeman N, Boggon TJ, Naoki K, Sasaki H, Fujii Y, Eck MJ, Sellers WR, Johnson BE, Meyerson M. EGFR mutations in lung cancer: correlation with clinical response to gefitinib therapy. Science. 2004;304(5676):1497-500.

2. Lynch TJ, Bell DW, Sordella R, Gurubhagavatula S, Okimoto RA, Brannigan BW, Harris PL, Haserlat SM, Supko JG, Haluska FG, Louis DN, Christiani DC, Settleman J, Haber DA. Activating mutations in the epidermal growth factor receptor underlying responsiveness of non-small-cell lung cancer to gefitinib. N Engl J Med. 2004;350(21):2129-39.

3. Sordella R, Bell DW, Haber DA, Settleman J. Gefitinib-sensitizing EGFR mutations in lung cancer activate anti-apoptotic pathways. Science. 2004;305(5687):1163-7.

4. Mok TS, Wu YL, Thongprasert S, Yang CH, Chu DT, Saijo $\mathrm{N}$, Sunpaweravong P, Han B, Margono B, Ichinose Y, Nishiwaki Y, Ohe Y, Yang JJ, Chewaskulyong B, Jiang H, Duffield EL, Watkins CL, Armour AA, Fukuoka M. Gefitinib or carboplatin-paclitaxel in pulmonary adenocarcinoma. $\mathrm{N}$ Engl J Med. 2009;361(10):947-57.
5. Rosell R, Carcereny E, Gervais R, Vergnenegre A, Massuti B, Felip E, Palmero R, Garcia-Gomez R, Pallares C, Sanchez JM, Porta R, Cobo M, Garrido P, Longo F, Moran T, Insa A, De Marinis F, Corre R, Bover I, Illiano A, Dansin E, de Castro J, Milella M, Reguart N, Altavilla G, Jimenez U, Provencio M, Moreno MA, Terrasa J, Muñoz-Langa J, Valdivia J, Isla D, Domine M, Molinier O, Mazieres J, Baize N, GarciaCampelo R, Robinet G, Rodriguez-Abreu D, Lopez-Vivanco G, Gebbia V, Ferrera-Delgado L, Bombaron P, Bernabe R, Bearz A, Artal A, Cortesi E, Rolfo C, Sanchez-Ronco M, Drozdowskyj A, Queralt C, de Aguirre I, Ramirez JL, Sanchez JJ, Molina MA, Taron M, Paz-Ares L, Spanish Lung Cancer Group in collaboration with Groupe Français de PneumoCancérologie and Associazione Italiana Oncologia Toracica. Erlotinib versus standard chemotherapy as first-line treatment for European patients with advanced EGFR mutation-positive non-small-cell lung cancer (EURTAC): a multicentre, open-label, randomised phase 3 trial. Lancet Oncol. 2012;13(3):239-46.

6. Soda M, Choi YL, Enomoto M, Takada S, Yamashita Y, Ishikawa $\mathrm{S}$, Fujiwara $\mathrm{S}$, Watanabe $\mathrm{H}$, Kurashina $\mathrm{K}$, Hatanaka H, Bando M, Ohno S, Ishikawa Y, Aburatani H, Niki T, Sohara Y, Sugiyama Y, Mano H. Identification of the transforming EML4-ALK fusion gene in non-small-cell lung cancer. Nature. 2007;448(7153):561-6.

7. Shaw AT, Kim DW, Nakagawa K, Seto T, Crinó L, Ahn MJ, De Pas T, Besse B, Solomon BJ, Blackhall F, Wu YL, Thomas M, O'Byrne KJ, Moro-Sibilot D, Camidge DR, Mok T, Hirsh V, Riely GJ, Iyer S, Tassell V, Polli A, Wilner KD, Jänne PA. Crizotinib versus chemotherapy in advanced ALK-positive lung cancer. N Engl J Med. 2013;368(25):2385-94.

8. Solomon BJ, Mok T, Kim DW, Wu YL, Nakagawa K, Mekhail T, Felip E, Cappuzzo F, Paolini J, Usari T, Iyer S, Reisman A, Wilner KD, Tursi J, Blackhall F; PROFILE 1014 Investigators. First-line crizotinib versus chemotherapy in ALK-positive lung cancer. N Engl J Med. 2014;371(23):2167-77

9. Shih JY, Gow $\mathrm{CH}$, Yang PC. EGFR mutation conferring primary resistance to gefitinib in non-small-cell lung cancer. N Engl J Med. 2005;353(2):207-8.

10. Choi YL, Soda M, Yamashita Y, Ueno T, Takashima J, Nakajima T, Yatabe Y, Takeuchi K, Hamada T, Haruta H, Ishikawa Y, Kimura H, Mitsudomi T, Tanio Y, Mano H, ALK Lung Cancer Study Group. EML4-ALK mutations in lung cancer that confer resistance to ALK inhibitors. N Engl J Med. 2010;363(18):1734-9.

11. Cappuzzo F, Bemis L, Varella-Garcia M. HER2 mutation and response to trastuzumab therapy in non-small-cell lung cancer. N Engl J Med. 2006;354(24):2619-21.

12. Langer CJ, Stephenson P, Thor A, Vangel M, Johnson DH, Eastern Cooperative Oncology Group Study 2598. Trastuzumab in the treatment of advanced non-small-cell lung cancer: is there a role? Focus on Eastern Cooperative Oncology Group study 2598. J Clin Oncol. 2004;22(7):1180-7.

13. Mazières J, Peters $S$, Lepage $B$, Cortot $A B$, Barlesi F, BeauFaller M, Besse B, Blons $\mathrm{H}$, Mansuet-Lupo A, Urban T, Moro-Sibilot D, Dansin E, Chouaid C, Wislez M, Diebold J, Felip E, Rouquette I, Milia JD, Gautschi O. Lung cancer that harbors an HER2 mutation: epidemiologic characteristics and therapeutic perspectives. J Clin Oncol. 2013;31(16):1997-2003.

14. Gandhi L, Bahleda R, Tolaney SM, Kwak EL, Cleary JM, Pandya SS, Hollebecque A, Abbas R, Ananthakrishnan R, Berkenblit A, Krygowski M, Liang Y, Turnbull KW, Shapiro GI, Soria JC. Phase I study of neratinib in combination with temsirolimus in patients with human epidermal growth factor receptor 2-dependent and other solid tumors. J Clin Oncol. 2014;32(2):68-75. 
15. Weiler D, Diebold J, Strobel S, Aebi S, Gautschi O. Rapid response to trastuzumab emtansine (T-DM1) in a patient with HER2-driven lung cancer. J Thorac Oncol. 2014 (in press)

16. Bergethon $\mathrm{K}$, Shaw AT, Ou SH, Katayama R, Lovly CM, McDonald NT, Massion PP, Siwak-Tapp C, Gonzalez A, Fang R, Mark EJ, Batten JM, Chen H, Wilner KD, Kwak EL, Clark JW, Carbone DP, Ji H, Engelman JA, Mino-Kenudson M, Pao W, Iafrate AJ. ROS1 rearrangements define a unique molecular class of lung cancers. J Clin Oncol. 2012;30(8):863-70.

17. Shaw AT, Ou SH, Bang YJ, Camidge DR, Solomon BJ, Salgia R, Riely GJ, Varella-Garcia M, Shapiro GI, Costa DB, Doebele RC, Le LP, Zheng Z, Tan W, Stephenson P, Shreeve SM, Tye LM, Christensen JG, Wilner KD, Clark JW, Iafrate AJ. Crizotinib in ROS1-rearranged non-small-cell lung cancer. N Engl J Med. 2014;371:1963-71.

18. Mazières J, Zalcman G, Crinò L, Biondani P, Barlesi F, Filleron T, Dingemans AM, Léna $\mathrm{H}$, Monnet I, Rothschild SI, Cappuzzo F, Besse B, Thiberville L, Rouvière D, Dziadziuszko R, Smit EF, Wolf J, Spirig C, Pecuchet N, Leenders F, Heuckmann JM, Diebold J, Milia JD, Thomas RK, Gautschi O. Crizotinib therapy for advanced lung adenocarcinoma and a ROS1 rearrangement: results from the EUROS1 cohort. J Clin Oncol. 2014 (in press).

19. Awad MM, Katayama R, McTigue M, Liu W, Deng YL, Brooun A, Friboulet L, Huang D, Falk MD, Timofeevski S, Wilner KD, Lockerman EL, Khan TM, Mahmood S, Gainor JF, Digumarthy SR, Stone JR, Mino-Kenudson M, Christensen JG, Iafrate AJ, Engelman JA, Shaw AT. Acquired resistance to crizotinib from a mutation in CD74-ROS1. N Engl J Med. 2013;368(25):2395-401.

20. Gautschi O, Pauli C, Strobel K, Hirschmann A, Printzen G, Aebi S, Diebold J. A patient with BRAF V600E lung adenocarcinoma responding to vemurafenib. J Thorac Oncol. 2012;7(10):e23-4.

21. Peters S, Michielin O, Zimmermann S. Dramatic response induced by vemurafenib in a BRAF V600E-mutated lung adenocarcinoma. J Clin Oncol. 2013;31(20):e341-4.

22. Litvak AM, Woo K, Hayes S, Huang J, Rimner A, Sima CS, Moreira AL, Tsukazan M, Riely GJ. Clinical characteristics and outcomes for patients with thymic carcinoma: evaluation of masaoka staging. J Thorac Oncol. 2014;9(12):1810-5.
23. Planchard D, Kim TM, Mazières J, Quoix E, Riely GJ, Barlesi F, Souquet P, Smit EF, Groen HJ, Kelly R, Cho B, Socinski MA, Tucker C, Ma B, Mookerjee B, Curtis CM, Johnson BE. LBA38_PR-Dabrafenib in patients with BRAF V600Emutant advanced non-small cell lung cancer (NSCLC): a multicenter, open-label, phase II trial (BRF113928). Ann Oncol. 2014;25(5):1-41.

24. Gautschi O, Peters S, Zoete V, Aebersold-Keller F, Strobel K, Schwizer B, Hirschmann A, Michielin O, Diebold J. Lung adenocarcinoma with BRAF G469L mutation refractory to vemurafenib. Lung Cancer. 2013;82(2):365-7.

25. Wang R, Hu H, Pan Y, Li Y, Ye T, Li C, Luo X, Wang L, Li H, Zhang Y, Li F, Lu Y, Lu Q, Xu J, Garfield D, Shen L, Ji H, Pao W, Sun Y, Chen H. RET fusions define a unique molecular and clinicopathologic subtype of non-small-cell lung cancer. J Clin Oncol. 2012;30(35):4352-9.

26. Chao BH, Briesewitz R, Villalona-Calero MA. RET fusion genes in non-small-cell lung cancer. J Clin Oncol. 2012;30(35):4439-41.

27. Drilon A, Wang L, Hasanovic A, Suehara Y, Lipson D, Stephens P, Ross J, Miller V, Ginsberg M, Zakowski MF, Kris MG, Ladanyi M, Rizvi N. Response to Cabozantinib in patients with RET fusion-positive lung adenocarcinomas. Cancer Discov. 2013;3(6):630-5.

28. Gautschi O, Zander T, Keller FA, Strobel K, Hirschmann A, Aebi S, Diebold J. A patient with lung adenocarcinoma and RET fusion treated with vandetanib. J Thorac Oncol. 2013;8(5):e43-4.

29. Gautschi O, Pall G, Schultheis A, Aebersold F, Gardizi M, Heuckmann J, Merkelbach-Bruse S, Wolf J, Diebold J, Heukamp LC. 940-Lung adenocarcinoma with RET fusion: early experience with diagnosis and targeted therapy. J Thorac Oncol. 2014;9(S9):S7-52.

30. Falchook GS, Ordóñez NG, Bastida CC, Stephens PJ, Miller VA, Gaido L, Jackson T, Karp DD. Effect of the ret inhibitor vandetanib in a patient with RET fusion-positive metastatic non-small-cell lung cancer. J Clin Oncol. 2014 [Epub ahead of print].

31. http://www.nccn.org/professionals/physician_gls/f_ guidelines.asp\#site. 